https://doi.org/10.32689/2618-0065-2020-3(5)-195-203

Пархоменко-Куцевіл Оксана Ігорівна, доктор наук 3 державного управління, професор, професор кафедри публічного адміністрування, Міжрегіональна Академія управління персоналом, 03039, м. Київ, вул. Фрометівська, 2, тел.: 050-922-15-35, e-mail: pkoi@ukr.net, https://orcid.org/0000-0002-0758-346X

\title{
ІНФОРМАЦІЙНА ВІДКРИТІСТЬ СИСТЕМИ ПУБЛІЧНОГО УПРАВЛІННЯ ЯК ОСНОВА ЗАБЕЗПЕЧЕННЯ НАЦІОНАЛЬНОЇ БЕЗПЕКИ
}

Анотація. У статті системно проаналізовано проблему забезпечення інформаційної відкритості системи публічного управління як основи національної безпеки. Інформаційна відкритість органів публічного управління є ключовим інструментом для боротьби 3 корупцією, а також формування практичних засад забезпечення національної безпеки.

Обгрунтовано, що інформаційна відкритість системи публічного управління - це формування механізмів забезпечення надання інформації органами публічного управління безпосередньо або опосередковано з метою формування дієвого діалогу та співпраці 3 громадськістю, формування ефективних державно-управлінських рішень 3 важливих питань життєдіяльності суспільства.

Запропоновано розробити Стратегію розвитку інформаційного суспільства на 2021-2031 роки, де передбачити: по-перше, дієві механізми інформаційної відкритості, зокрема, проведення публічних звітувань органів державного управління та місцевого самоврядування; по-друге, впровадження механізмів громадського оцінювання такого звітування та наслідки щодо негативного оцінювання; по-трете, визначити основні загрози, які виникають внаслідок відсутності принципу відкритості у співпраці органів публічного управління та громадськості, визначення ефективних механізмів забезпечення такої співпраці.

Ключові слова: публічне управління, органи публічного управління, прозорість, транспарентність, відкритість, інформаційна прозорість, система національної безпеки.

\section{INFORMATION OPENNESS OF THE PUBLIC ADMINISTRATION SYSTEM AS A BASIS FOR ENSURING NATIONAL SECURITY}

Abstract. The article attempts to systematically analyze the problem of ensuring the information openness of the public administration system as a basis for national security. Information openness of public administration bodies is a key tool for combating corruption, as well as the formation of practical foundations for national security. 
The author substantiates that the information openness of the public administration system is the formation of mechanisms to ensure the provision of information by public administration directly or indirectly in order to form an effective dialogue and cooperation with the public, effective public administration decisions on important issues of society.

The article proposes to format a Strategy for the development of the information society for 2021-2031, which provides: first, real mechanisms of information openness, in particular, public reporting of public administration and local government; second, the introduction of mechanisms for public evaluation of such reporting and the consequences for negative evaluation; thirdly, to identify the main threats arising from the lack of the principle of openness in cooperation between public administration bodies and the public, to identify effective mechanisms for ensuring such cooperation.

Key words: public administration, public administration bodies, transparency, transparency, information transparency, national security system.

Постановка проблеми. Проблема відкритості органів державної влади та місцевого самоврядування $\epsilon$ основою формування громадянського суспільства, формування дієвої співпраці громадськості з органами публічної влади, опрацювання важливих державно-управлінських рішень 3 урахуванням усіх зацікавлених стейкхолдерів.

Надання оперативної достовірної інформації 3 метою формування ефективних рішень певних державно-управлінських проблем $є$ також основою формування національною безпекою України. Саме інформація виступає основою розуміння діяльності органів державної влади у той чи іншій ситуації. Від якісної інформаційної кампанії органу публічної алоди залежить підтримка та розуміння населення важливих кардинальних реформ та їх постійне удосконалення.

Крім того, від оперативності надання відповідної інформації щодо прийняття важливих державно-управлінських реформ залежить і підтримка громадськості таких реформ, що в свою чергу формує позитивне ставлення до дій органів публічного управління.

Аналіз останніх досліджень і публікацій. Проблему відкритості та прозорості діяльності органів влади досліджували такі науковці, як: Е. Афонін, О. Бабінова, І. Василенко, Ю. Габермас, Н. Гудима, Д. Гунін, I. Жаровська, В. Мельниченко, І. Ібрагімова, В. Комаровський, С. Телешун, $€$. Тихомирова та ін. Усі зазначені науковці акцентували увагу на різних аспектах забезпечення відкритості та прозорості органів влади, визначали складові відкритості та прозорості діяльності органів влади, але розробки щодо інформаційної відкритості системи публічного управління як основи забезпечення національної безпеки відсутні.

Метою статті $\epsilon$ системний аналіз інформаційної відкритості системи публічного управління як основа забезпечення національної безпеки.

Виклад основного матеріалу. Загалом поінформованість суспільства $\epsilon$ одним 3 основних чинників його прогресивного розвитку, невід'ємною 
умовою демократії участі та важливою передумовою діяльності органів публічної влади. Забезпечення громадян, їх об’єднань та органів публічної влади інформацією, яка необхідна для реалізації ними своїх функцій, здійснюється, 3 одного боку, шляхом постійного технологічного вдосконалення діяльності засобів масової інформації, а з іншого - завдяки своєчасному конституційно-правовому регулюванню засад цього процесу. Причому головним завданням засобів масової інформації $\epsilon$ передусім об'єктивне інформування суспільства про все, що становить або може становити інтерес для нього або його складових частин [1, с. 69].

На нашу думку, інформаційна відкритість органів публічного управління є ключовим інструментом для боротьби 3 корупцією, а також формування практичних засад забезпечення національної безпеки. Адже надання об’єктивної інформації щодо прийняття або реалізації важливих державно-управлінських рішень знімає соціальну напругу населення, зменшує супротив реформам, збільшує довіру населення до органів публічної влади.

Крім того, маніпулювання інформацією органами публічної влади призводить до викривленого сприйняття державно-управлінських рішень та прогресивних реформ, водночас замовчування такої інформації призводить до спротиву реформам та важливим рішенням.

Стратегічними засади національної безпеки є не тільки забезпечення військової безпеки населення країни, іiі кордонів, територій, а й забезпечення інформаційною безпекою. Інформаційна безпека - це стан захищеності життєво важливих інтересів людини, суспільства i держави від інформаційний війн, негативних інформаційних впливів, несанкціонованого створення, розповсюдження, використання свідомо спрямованої із визначеною метою неповної, невчасної, невірогідної та упередженої інформації. Тому, від інформаційної відкритості органів публічної влади залежить і формування заходів з забезпечення інформаційної безпеки, яка $є$ основою національної безпеки України.

На сьогодні спостерігається ситуація, коли населення не поінформовано про важливі кроки Уряду України, Парламенту України, органів місцевого самоврядування щодо карантинних обмежень та подальших кроків зазначених органів влади щодо продовження карантину в країні та регіонах. У зв’язку з цим, громадяни не розуміють подальших дій органів публічної влади та не підтримують такі обмеження, а внаслідок цього населення не дотримуються карантинних обмежень, що призводить до збільшення захворюваності населення країни. Тобто інформаційна відкритість органів державної влади відіграє важливу роль у дотриманні таких карантинних обмежень і зменшенні захворюваності. Часто населення не обізнано з питань причин запровадження суворих карантинних заходів, не дотримуються карантину у зв'язку з обмеженням доступу до інформації щодо поширення хвороби та іiі наслідки. Тому питання інформаційної відкритості органів публічної влади є стратегічним питанням забезпечення національної безпеки України. 
Такий підхід дає змогу розширити систему стримувань і противаг адміністративній владі за допомогою права на інформацію та громадський контроль, який це право активізує [2]. Підвищення відкритості органів влади спрямоване на:

демократичний розвиток;

інструмент забезпечення підконтрольності влади;

засіб підвищення активності громадян, їхньої свідомості і політичної культури;

результат розвитку комунікацій між різними учасниками демократичного процесу;

форму реалізації права громадян на повну й об'єктивну інформацію. [3, c. 41].

Відкритий доступ до інформації дозволяє підвищити відповідальність державних службовців і службовців органів місцевого самоврядування, позитивно впливає на ефективність боротьби з корупцією, зі зловживанням службовим становищем.

Інформаційна відкритість системи публічного управління - це формування механізмів забезпечення надання інформації органами публічного управління безпосередньо або опосередковано 3 метою формування дієвого діалогу та співпраці 3 громадськістю, формування ефективних державно-управлінських рішень 3 важливих питань життєдіяльності суспільства.

Головним механізмом забезпечення відкритості системи публічного управління в системі національної безпеки $є$ закони України ««Про інформацію», «Про звернення громадян», «Про порядок висвітлення діяльності органів державної влади та органів місцевого самоврядування в Україні засобами масової інформації», «Про інформаційні агентства», «Про друковані засоби масової інформації (пресу) в Україні», «Про телебачення і радіомовлення», «Про доступ до публічної інформації», «Про захист персональних даних», «Про державну таємницю», розпорядження Кабінету Міністрів України «Про роботу центральних і місцевих органів виконавчої влади щодо забезпечення відкритості у своїй діяльності, зв'язків 3 громадськістю та взаємодії із засобами масової інформації» та ін.

Відповідно до Закону України «Про інформацію» основними напрямами державної інформаційної політики як основи національної безпеки є:

забезпечення доступу кожного до інформації;

забезпечення рівних можливостей щодо створення, збирання, одержання, зберігання, використання, поширення, охорони, захисту інформації;

створення умов для формування в Україні інформаційного суспільства;

забезпечення відкритості та прозорості діяльності суб'єктів владних повноважень;

створення інформаційних систем i мереж інформації, розвиток електронного урядування; 
постійне оновлення, збагачення та зберігання національних інформаційних ресурсів;

забезпечення інформаційної безпеки України;

сприяння міжнародній співпраці в інформаційній сфері та входженню України до світового інформаційного простору [4].

Право на інформацію забезпечується:

створенням механізму реалізації права на інформацію;

створенням можливостей для вільного доступу до статистичних даних, архівних, бібліотечних і музейних фондів, інших інформаційних банків, баз даних, інформаційних ресурсів;

обов'язком суб'єктів владних повноважень інформувати громадськість та засоби масової інформації про свою діяльність і прийняті рішення;

обов'язком суб'єктів владних повноважень визначити спеціальні підрозділи або відповідальних осіб для забезпечення доступу запитувачів до інформації;

здійсненням державного i громадського контролю за додержанням законодавства про інформацію;

встановленням відповідальності за порушення законодавства про інформацію [4].

Відповідно до Закону України «Про доступ до публічної інформації» [5] право на доступ до публічної інформації гарантується: обов'язком розпорядників інформації надавати та оприлюднювати інформацію, крім випадків, передбачених законом; визначенням розпорядником інформації спеціальних структурних підрозділів або посадових осіб, які організовують у встановленому порядку доступ до публічної інформації, якою він володіє; максимальним спрощенням процедури подання запиту та отримання інформації; доступом до засідань колегіальних суб'єктів владних повноважень, крім випадків, передбачених законодавством; здійсненням парламентського, громадського та державного контролю за дотриманням прав на доступ до публічної інформації; юридичною відповідальністю за порушення законодавства про доступ до публічної інформації [5].

Доступ до публічної інформації відповідно до цього Закону здійснюється на принципах:

1) прозорості та відкритості діяльності суб'єктів владних повноважень;

2) вільного отримання, поширення та будь-якого іншого використання інформації, що була надана або оприлюднена відповідно до цього Закону, крім обмежень, встановлених законом;

3) рівноправності, незалежно від ознак раси, політичних, релігійних та інших переконань, статі, етнічного та соціального походження, майнового стану, місця проживання, мовних або інших ознак [5].

Важливими механізмами у забезпеченні інформаційної відкритості системи публічного управління як основи національної безпеки $\epsilon$ запровадження трьох механізмів, що грунтуються на використанні низки електронних інструментів. 
1. Електронні петиції. Відповідно до статті 23 Закону України «Про звернення громадян» громадяни можуть звернутися до Президента України, Верховної Ради України, Кабінету Міністрів України, органу місцевого самоврядування з електронними петиціями через офіційний вебсайт органу, якому вони адресовані, або веб-сайт громадського об'єднання, що здійснює збір підписів на підтримку електронної петиції. В електронній петиції має бути викладено суть звернення, зазначено прізвище, ім'я, по батькові автора (ініціатора) електронної петиції, адресу електронної пошти. На веб-сайті відповідного органу або громадського об'єднання, що здійснює збір підписів, обов'язково зазначають дату початку збору підписів та інформацію щодо загальної кількості та переліку осіб, які підписали електронну петицію [6].

2. ProZorro - електронна система публічних закупівель, яка прийшла на зміну паперовим державним тендерам, інформація про які зазвичай не була доступна широкій громадськості. Відповідно до статті 1 Закону України «Про публічні закупівлі», має бути створено веб-портал уповноваженого органу 3 питань закупівель, що $\epsilon$ інформаційно-телекомунікаційною системою, до складу якої належать модуль електронного аукціону і база даних. Він $є$ частиною електронної системи закупівель та забезпечує створення, зберігання й оприлюднення всієї інформації про закупівлі, проведення електронного аукціону, автоматичний обмін інформацією, документами та користування сервісами 3 автоматичним обміном інформацією, доступ до якого здійснюється за допомогою мережі Інтернет. Функціонування веб-порталу уповноваженого органу уможливлюється, зокрема, завдяки наданню авторизованим електронним майданчикам платного доступу до модуля електронного аукціону та бази даних. Порядок надання доступу та розмір плати встановлює Кабінет Міністрів України [7].

3. Електронне декларування. Відповідно до ст. 45 Закону України «Про запобігання корупції», особи, уповноважені на виконання функцій держави або місцевого самоврядування, зобов'язані щорічно до 1 квітня подавати шляхом заповнення на офіційному веб-сайті Національного агентства декларацію особи, уповноваженої на виконання функцій держави або місцевого самоврядування за минулий рік за формою, що визначається Національним агентством [8].

Електронне декларування стало справжнім революційним проривом, оскільки вперше в історії України було надано доступ для широкої громадськості до способу життя високо посадовців 3 метою виявлення порушень антикорупційного законодавства [9].

Разом 3 тим, на сьогодні існує проблема відсутності відкритості у діяльності органів публічного управління, адже, по-перше, органи публічного управління не завжди вчасно інформують громадськість про важливі державно-управлінські рішення, з метою уникнення негативного ставлення, по-друге, відсутність реальних інформаційних кампаній щодо роз'яснення рішень, які стратегічно впливають на життєдіяльність суспільства, по-третє, відсутність інформаційної культури у населення та негативного ставлення до всіх дій органів державної влади та місцевого самоврядування. 
Одним із стратегічних механізмів забезпечення інформаційної відкритості системи публічного управління як основи забезпечення національної безпеки $є$ формування Стратегії розвитку інформаційного суспільства на 2021-2031 роки, де передбачити реальні механізми інформаційної відкритості, зокрема, проведення публічних звітувань органів державного управління та місцевого самоврядування, впровадження механізмів громадського оцінювання такого звітування та наслідки щодо негативного оцінювання.

Так, оцінювання громадськості повинні проходити не лише дії органів державного управління та місцевого самоврядування, а й результати діяльності керівників таких органів, їх наслідки та подальші дії.

Крім того, у Стратегії розвитку інформаційного суспільства на 20212031 роки потрібно визначити основні загрози, які виникають внаслідок відсутності принципу відкритості у співпраці органів публічного управління та громадськості, визначення ефективних механізмів забезпечення такої співпраці.

Висновки та перспективи подальших досліджень. Автором обгрунтовано, що інформаційна безпека - це стан захищеності життєво важливих інтересів людини, суспільства і держави від інформаційний війн, негативних інформаційних впливів, несанкціонованого створення, розповсюдження, використання свідомо спрямованої із визначеною метою неповної, невчасної, невірогідної та упередженої інформації. Тому, від інформаційної відкритості органів публічної влади залежить і формування заходів з забезпечення інформаційної безпеки, яка $є$ основою національної безпеки України. Автором 3'ясовано, що інформаційна відкритість системи публічного управління - це формування механізмів забезпечення надання інформації органами публічного управління безпосередньо або опосередковано 3 метою формування дієвого діалогу та співпраці 3 громадськістю, формування ефективних державно-управлінських рішень 3 важливих питань життєдіяльності суспільства.

Виокремлено основні заходи забезпечення інформаційної відкритості органів публічної влади та запропоновано розробити та затвердити Стратегію розвитку інформаційного суспільства на 2021-2031 роки. Зазначена стратегія передбачатиме формування інформаційної відкритості органів публічної влади як основи національної безпеки України.

У перспективі подальших розвідок передбачено проаналізувати систему інформаційної відкритості органів державної влади за кордоном, визначення закономірностей розвитку інформаційної відкритості.

\section{Література:}

1. Нестерович В. Ф. Принципи відкритості та прозорості в діяльності органів державної влади як передумова утвердження демократії участі. Філософські ma методологічні проблеми права. 2016. № 2 (12). С. 67-77.

2. Сірант О.Р. Відкритість інформації одна 3 умов розвитку громадянського суспільства в Україні. URL: http://aphd.ua/publication-172/ (дата звернення 03.07.2020). 
3. Тихомирова С. Б. Транспарентність і відкритість діяльності влади ta шляхи їх забезпечення в Україні. Наукові записки. Політичні науки. 2002. Том 20. С. 40-43.

4. Про інформацію: Закон України від 02.10.1992 № 2657-XII // База даних «Законодавство України». / ВР України. URL: http://zakon4.rada.gov.ua/laws/show/2657-12

5. Про доступ до публічної інформації: Закон України від 13.01.2011 №2939-17 // База даних «Законодавство України». / BP України. URL: https://zakon.rada.gov.ua/laws/show/2939-17\#Text (дата звернення 03.07.2020).

6. Про звернення громадян: Закон України від 02.10.1996 № 393/96-ВР // База даних «Законодавство України». / BP України. URL: https://zakon2.rada.gov.ua/laws/show/393/96\%D0\%B2\%D1\%80\#Text (дата звернення 03.07.2020).

7. Про публічні закупівлі: Закон України від 25.12.2015 №922-19 // База даних «Законодавство України». / ВP України. URL: https://zakon.rada.gov.ua/laws/show/92219\#Техt (дата звернення 03.07.2020).

8. Про запобігання корупції: Закон України від 14.10.2014. №1700-18 // База даних «Законодавство України». / ВР України. URL: https://zakon.rada.gov.ua/laws/show/170018\#Техt (дата звернення 03.07.2020).

9. Е-декларування: перші підсумки. URL: http://bbc.in/2fiBKXm. (дата звернення 03.07.2020).

\section{References:}

1. Nesterovych, V. F. (2016) Pryntsypy vidkrytosti ta prozorosti v diialnosti orhaniv derzhavnoi vlady yak peredumova utverdzhennia demokratii uchasti [Principles of openness and transparency in the activities of public authorities as a prerequisite for the establishment of participatory democracy]. Filosofski ta metodolohichni problemy prava - Philosophical and methodological problems of law, 2 (12), 67-77 [in Ukrainian].

2. Sirant, O.R. Vidkrytist informatsii odna $\mathrm{z}$ umov rozvytku hromadianskoho suspilstva $\mathrm{v}$ Ukraini [Openness of information is one of the conditions for the development of civil society in Ukraine.]. Retrieved from http://aphd.ua/publication-172/ [in Ukrainian].

3. Tykhomyrova, Ye. B. (2002) Transparentnist i vidkrytist diialnosti vlady ta shliakhy yikh zabezpechennia v Ukraini [Transparency and openness of government and ways to ensure them in Ukraine]. Naukovi zapysky. Politychni nauky - Proceedings. Political science, 20, 40-43 [in Ukrainian].

4. Zakon Ukrainy pro informatsiiu [Law of Ukraine on Information] zakon.rada.gov. Retrieved from http://zakon4.rada.gov.ua/laws/show/2657-12 [in Ukrainian].

5. Zakon Ukrainy pro dostup do publichnoho informatsii [Law of Ukraine on access to public information] zakon.rada.gov. Retrieved from https://zakon.rada.gov.ua/laws/show/293917\#Text [in Ukrainian].

6. Zakon Ukrainy pro zvernennia hromadian [Law of Ukraine on citizens' appeals] zakon.rada.gov. Retrieved from https://zakon2.rada.gov.ua/laws/show/393/96\%D0\%B2\%D1\%80\#Text [in Ukrainian].

7. Zakon Ukrainy pro publichni zakupivli [Law of Ukraine on Public Procurement.] zakon.rada.gov. Retrieved from https://zakon.rada.gov.ua/laws/show/922-19\#Text [in Ukrainian]

8. Zakon Ukrainy pro zapobihannia koruptsii [Law of Ukraine on Prevention of Corruption] zakon.rada.gov. Retrieved from https://zakon.rada.gov.ua/laws/show/1700-18\#Text [in Ukrainian].

9. E-deklaruvannia: pershi pidsumky [E-declaration: the first results]. Retrieved from http://bbc.in/2fiBKXm. [in Ukrainian]. 